\title{
The unobserved economy and the Dutch national accounts after the benchmark revision 2015
}

Brugt Kazemier, Michel van Veen, Sander IJmker

To cite this article: Kazemier, B., van Veen, M., \& IJmker, S. (2019). The unobserved economy and the Dutch national accounts after the benchmark revision 2015. Central European Economic Journal, 6(53), 1-24.

DOI: 10.2478/ceej-2019-0002.

To link to this article: https://doi.org/10.2478/ceej-2019-0002 


\title{
The unobserved economy and the Dutch national accounts after the benchmark revision 2015
}

\begin{abstract}
In 2018, Statistics Netherlands carried out a general benchmark revision of their national accounts statistics. The base year was 2015. Special attention was paid to the exhaustiveness of the estimates. Among other, these include estimates for illegal activities and tax evasion. In the first step, the main (illegal and off the record) activities that were not included in the regular data sources underlying the national accounts were identified. In the second step, estimates were made for each identified activity, based on the scarce information data sources available, supplemented with assumptions. This paper describes the second step. The value added of illegal activities in 2015 was estimated at 4.8 billion euros, which is $0.7 \%$ of gross domestic product (GDP). The explicit adjustment for tax evasion was about 3.9 billion euros, which is slightly $<0.6 \%$ of GDP.
\end{abstract}

Keywords: national accounts, illegal activities, tax evasion, underground economy

JEL Codes: E01, E26

\section{Introduction}

The national accounts provide a quantitative description of the economic development of a country. The information required for the compilation of the national accounts is obtained from a wide variety of sources. Changes in data sources and the availability of new data sources can lead to new insights in the level and growth rates of important economic indicators in the national accounts. New sources, new insights, new definitions of variables in the national accounts and new estimate and data collection techniques necessitate occasional benchmark revisions. The recent 2015 benchmark revision of the Dutch national accounts is an example. In this revision, new requirements and recommendations of Eurostat to improve the quality of the estimates are introduced.

One important concern in the compilation of national accounts, and especially in a benchmark revision, is the exhaustiveness of the national accounts statistics. This is especially relevant as national accounts statistics need to be comparable over time and among countries. Legalisation of prostitution, for example, may not lead to sudden and one-time additional economic growth, just because of that legalisation. And gross national income (GNI) in one country may not differ from GNI elsewhere because of differences in the legalisation of prostitution. Therefore, national accounts statistics must include an estimate for all relevant activities. This article focuses on the revised estimates to assure the exhaustiveness of the Dutch national accounts.

According to the SNA, unobserved activities can be classified into "underground activities for statistical reasons", "underground activities for economic reasons", "informal activities" (ILO definition) and "illegal activities". The ISTAT framework (Calzaroni, 2000; OECD/IMF/ILO/CIS STAT, 2002, pp. 42-45) is built upon this classification (Figure 1). It can be used to identify the main reasons for lack of exhaustiveness and the way they affect statistical observation. 


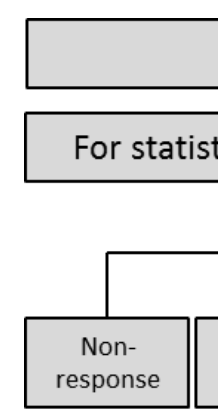

T1

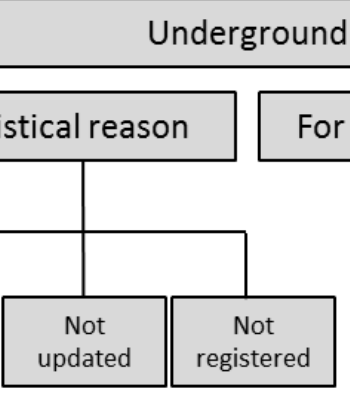

T2

T3

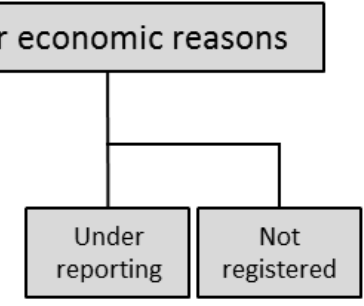

T4

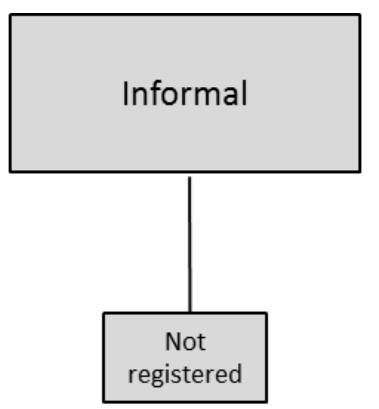

T6

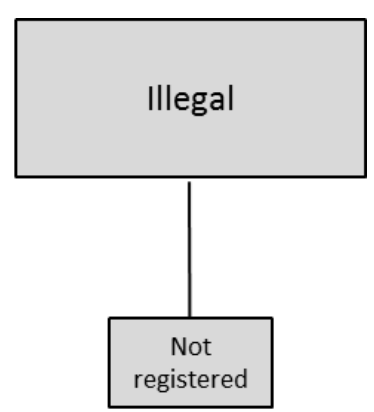

T7

Fig. 1: The ISTAT framework for exhaustiveness.

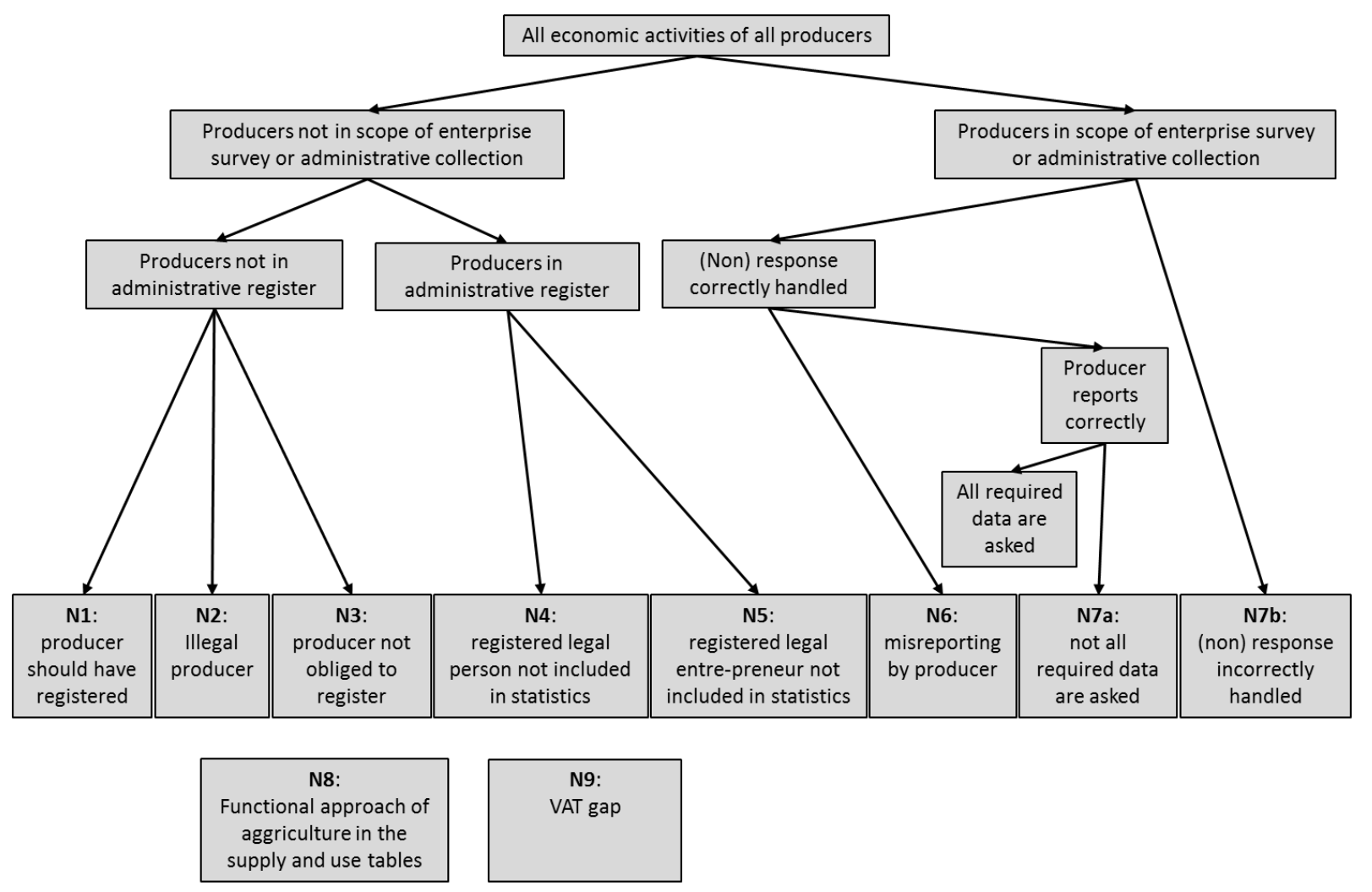

Fig. 2: Types of inexhaustiveness.

Based on this ISTAT framework, Eurostat developed a tabular framework in the course of their technical assistance to, at that time, the European Candidate Countries (Figure 2). A new category (N7) was added which included a large number of reasons for lack of exhaustiveness. These "other non-observed activities" include income which, in general, is not asked for in surveys, for example production for own final use, tips, wages and salaries in kind. Recently, another two categories were added to the framework. The first is the adjustments because of the functional approach of agriculture in the supply and use tables (N8). This means that all side activities that are not agriculture, for example the exploitation of a small campsite, have to be removed. The second new exhaustiveness category is the effect of the elimination of the VAT gap between 
theoretical and accrual VAT receipts of the government. This, for instance, includes the VAT that is paid for but not transferred to the tax authorities because of bankruptcy.

An important difference between the ISTAT framework and the Eurostat tabular approach is that the first is primarily a classification of the transaction (legal or not, tax evasion or not, informal or not), whereas the latter is primarily a classification of the actors (registered or not, included in observation or not). Here, we follow Eurostat's tabular approach as that is the framework that has been prescribed by Eurostat for the national inventories of methods and sources.

As about $70 \%$ of the total contributions of the member states to the budget of the European Union (EU) are charged pro rata to the GNI, the quality of the estimates of GNI is strictly monitored by Eurostat. Estimates must be detailed, sufficiently comparable between countries and over time, sources used must directly relate to the transactions being measured and methods used must be well described. Therefore, statistical agencies use the so-called collage method, combining a wide variety of sources and estimates to assure exhaustiveness. This article is an example, in this case for the Netherlands. The aim of this article is to challenge researchers outside of statistical agencies to comment and to improve the methods to improve future estimates for exhaustiveness. The second aim is to provide researchers with not easy to find detailed data (Tables 2-4) that may be useful for their estimates of the unobserved economy.

This article heavily relies on internal memoranda on methods and sources used to compile national accounts and, as far as still relevant, on the publicly available inventory of methods and sources (Statistics Netherlands, 2017) written after the implementation of the 2010 edition of the European System of Accounts (Eurostat, 2013). Section 2 gives an outline of the compilation process of the Dutch national accounts. Section 3 briefly summarises the history of the research on the unobserved economy, conducted by Statistics Netherlands. Section 4 gives an overview of all current explicit estimates made to assure the exhaustiveness of the estimates of national income.

Although the adjustments for exhaustiveness are meant to make the estimates of gross domestic product
(GDP) and GNI comparable between countries, the adjustments themselves are not comparable as these are closely related to the possibilities available to the statistical agencies. What is missed in one country when observing activities, and therefore is part of the adjustments for exhaustiveness, may well have been observed in another country. The only exception are the adjustments for illegal activities. These are comparable to a large extent. In Section 5, the adjustments for illegal activities in the Dutch national accounts are compared with those in other EU countries. The article concludes in Section 6.

\section{The compilation of the Dutch national accounts}

There are three methods to estimate national income: the income method (the sum of all kinds of incomes in a country), the expenditure method (the sum of household and government consumption, investment and the balance of exports and imports) and the production method (total production minus intermediate consumption). The Dutch national accounts are mainly compiled using the production approach. Annually, detailed supply and use tables are compiled: 635 product categories, 20 value-added components, 128 industries, 20 expenditure categories, 22 types of taxes and subsidies on products and 5 types of trade and transport margins. Expenditure is also estimated in the context of the supply and use table, where independent estimates of output, intermediate consumption and final use are compared and brought into balance. This integrated procedure allows for coordination of the GDP expenditure and production approaches. Tables are compiled in current year's prices and in preceding year's prices to achieve an accurate breakdown of value changes into volume changes and price changes. Simultaneously, a detailed set of labour accounts (number of workers, labour volume and wages, etc. per industry) is produced. Figures and developments per industry must match those in the national accounts and vice versa. 


\subsection{Valuation}

Three types of valuation are applied for domestically produced goods: "basic price", "producer's price" and "purchaser's price". The basic price is the final amount received by the producer. This is often different from the price the producer must charge (the producer's price), since the latter also takes account of taxes on products (such as excise duties) and production subsidies. The purchaser's price is the price paid by the customer (after the deduction of VAT, which is thus - still - not included in the purchaser's price), which is the producer's price augmented by possible transport and trade margins in respect of the product in question.

Imported goods and services are valued at "purchaser's price" and "c.i.f. price" The difference is that Netherlands' trade and transport margins, import taxes (as plus items) and re-export subsidies (as minus items) are included in the former but not in the latter.

Use table figures are quoted in purchaser's prices. In the supply table, domestic production figures are quoted in basic prices and imports in c.i.f. prices. For the difference, the supply tables are supplemented by three columns: trade and transport margins, taxes on products per product group and subsidies on products per product group. In the input-output table, domestically produced goods are valuated at producer's prices and imported goods at c.i.f. prices.

\subsection{Transition from commercial accounting to national accounts}

In compiling the national accounts, a number of concepts are not used in the same way as in commercial accounting owing to the (international) agreements applicable to such concepts. One long-established example is "depreciation". Commercial accounting deals with depreciation periods valid from physical, economic, administrative or fiscal point of view. As a result, depreciation periods for similar assets vary between enterprises. This is undesirable from the national accounts' point of view. Consequently, it was decided some considerable time ago to recalculate depreciation for national accounts' purposes, using the so-called perpetual inventory method.

\subsection{Role of direct and indirect estimation methods}

In general, estimates are based on observation and/ or annual reports, as far as possible. Otherwise, use is made of indirect calculations or reliable (possibly indirect) base-year estimates extrapolated with the help of indicators.

To a considerable extent, agricultural statistics are based on estimates of volume (observations and harvest estimates) multiplied by prices identified in other sectors. Industrial and construction sector estimates are likewise largely based on observation (production statistics), although only raised sampling values are available for many smaller enterprises.

Data for all industrial enterprise categories are estimated in the same general way, except for the food industry. The same procedure cannot be applied in this case, as observation largely relates to financial years which do not coincide with calendar years.

Data collection and preparation for the integration process is a multi-stage operation that differs by size of the enterprise, as the available data for larger enterprises is in general more detailed than for smaller enterprises. All data are grossed up to reflect the complete sizecategory population before the start of the integration process of the national accounts.

The most important analyses carried out during the integration process of the national accounts are the annual current price comparisons and the constant price calculations. For the latter, a price index is drawn up for each commodity category, using all available price information at Statistics Netherlands - production price indices, consumer price indices and producer price indices per product category for domestic output, exports and imports, collectively agreed wage changes et cetera - or elsewhere, for example the Dutch Central Bank (exchange rates) and annual business reports.

Other analyses conducted relate to the plausibility of estimated developments, the ratio between domestic and foreign sales, the ratio between domestic product and import, the development of production and consumption volumes, trends in employee output and value added, the development of the wage bill per employee, and the relationship between other income and the number of businesses per size category and legal form. 
Finally, analyses are conducted for each product category of which supply and demand are balanced. This sometimes leads to data replacement within a comparable commodity category. Value added may be adjusted after comparison with the labour accounts and discussions with the relevant sector experts.

\subsection{Government final expenditure}

The sector accounts are compiled simultaneously with the supply and use tables. This is especially the case for financial institutions and for government. The sources used to compile government production and government final expenditure are the same as those used for compiling the government sector accounts. The adjustments made in the context of the supply and use framework are validated against their impact on the sector accounts.

\subsection{Household final consumption expenditure}

The majority of household final expenditure is accounted for by household spending on goods and services. Its calculation is essentially based on the household budget survey and on retail trade statistics. The household budget survey collects expenditure data from a random sample of households over a calendar year. In addition to these data, information is available on income and household composition and other characteristics. This is used to compile an expenditure model for a number of household types.

Household consumption is linked to retail turnover. Consumers buy most of their goods from retail outlets and via the internet. In turn, most retailers sell almost all their goods to consumers. Retail trade statistics indicate retail turnover broken down by sales category.

Nevertheless, household consumption cannot be fully described with reference to the above-mentioned sources owing to definitional and population differences relative to the national accounts. For example, institutional households are not included in the household budget survey, whereas they should be included according to the definitions of the national accounts.

In calculating household consumption, expenditure levels are estimated for a base year. The current base year is 2015. The figures for the following years are calculated by means of expenditure trend estimates.

\subsection{Balancing}

Data sources almost never match. Therefore, after having filled the supply and use tables and the sector accounts with the data from numerous sources, the system has to be balanced such that all identities in the system are met. In the first stage of the balancing process, the largest discrepancies between supply and use are investigated. These large discrepancies are very often caused by errors in the data sources or by significant changes in the observation. Correction for these large discrepancies is a manual process that requires the expertise and involvement of specialist. In the second stage, the minor discrepancies are solved through automatic balancing, which takes account of the statistical variation of and restrictions on the data used (Bikker et al., 2013). The balancing process entails a simultaneous balancing of values (prices of the current year) and volumes (prices of previous year)

Contrary to the process described above, the balancing for a benchmark revision is done manually. The reason for this is that the automatic balancing procedure uses weights and restrictions which result from a previous year balancing. For a benchmark year, all weights and restrictions are re-examined. Furthermore, the balancing of a benchmark year is in current prices only.

After the balancing is completed, the results are discussed in small groups of experts, some of whom have not been involved in the compilation process. They pay special attention to figures that seem to be outliers and compare the figures with other statistics that were not used in the balancing process. This final review sometimes leads to a small number of improvements.

\section{Brief history of the research at Statistics Netherlands on the unobserved economy}

The oldest interest in the size of the unobserved economy is by statisticians and by tax specialists. The discussion about which activities should or should not 
be included in the national accounts is not new, see for example Kuznets (1941). Also the reliability and the exhaustiveness of national accounts and other statistics were subjects of research at an early stage, see inter alia Derksen (1939) and Statistics Netherlands (1951).

One of the earliest estimates of the hidden economy that was found, is by Helfferich (1914). In his estimate of the national income of Germany, he assumes that $10 \%$ is hidden from the tax authorities: Für das an sich steuerpflichtige, durch die Veranlagung aber nicht erfasste Einkommen ist ein nicht unerheblicher Zuschlag zu machen, der vorwiegend aufetwa $10 \%$ geschätzt wird. Based on these estimates and stating that the tax laws in Germany are more strict than in the Netherlands and that the tax moral in the Netherlands is worse than in Germany, Bonger (1915) assumes that $20 \%$ of Dutch national income in 1913 is hidden. For 1919 and further, he lowers this estimate to $10 \%$ because of new tax laws and improved control options (Bonger, 1923).

In 1939, new estimates became available: de Langen (1939) estimates income tax fraud at 6.2\% in 1929 and $4.4 \%$ in 1934. Also Statistics Netherlands was already researching the size of the hidden economy at that time. It used a $10 \%$ surcharge on top of the non-hidden income. The archive material underlying this estimate shows that another proposal has been considered also (Table 1).

Since the second half of the 1970s, there has also been an academic interest in the size of the hidden economy. The macro-economic theory had not been able to predict the developments that are important for economic planning and economic policy. This was attributed by Feige (1979) to the incompleteness of the statistical information. Since then academia has developed a large number of methods to estimate the missing statistical information (Kazemier, 2006; Schneider and Buehn, 2018), which is referred to in various ways such as hidden economy, underground economy, unrecorded economy, informal economy, etc. The outcome of most academic research was (and still is) that national income and economic growth were strongly underestimated.

Most statisticians, however, were not impressed by these results. They did not believe that national income and economic growth were underestimated to the extent that academic research suggested. Nevertheless, it was
Tab. 1: Proposed estimate for fraud as percentage of total national income, 1920-1938

$\left.\begin{array}{ll}\hline 1921 & 10 \\ 1922 & 9.5 \\ 1923 & 9 \\ 1924 & 8.5 \\ 1925 & 8 \\ 1926 & 7.5 \\ 1927 & 7 \\ 1928 & 6.5\end{array}\right] \begin{aligned} & \text { Bonger } \\ & (1923)\end{aligned}$

Source: Archive Statistics Netherlands.

a wake-up call. For Statistics Netherlands, at least, this was a reason to intensify the research on the unobserved economy, using the techniques they are familiar with. Surveys into tax evasion in home maintenance and improvement (Kazemier, 1984), car maintenance and home-coming hairdressers were conducted. In addition, Broesterhuizen (1985) made an estimate of the maximum distortion of national income, based on the sensitivity to fraud of the various methods and sources used in compiling national accounts. 
In 1983 and 1984, van Eck and Kazemier (1988, 1989) conducted a survey into the possibilities of hidden workers admitting their hidden activities. They experimented with the way the sensitive topic of the research was introduced (fairly direct or very gradually) and the way the surveyors were approached (face-to-face, by telephone, in written via the post, face-to-face with partly a free conversation instead of a questionnaire). The conclusion was that a gradual introduction of the topic was superior to the more direct introduction and that the face-to-face surveys outperformed the other ones. Asking the sensitive questions in a free conversation yielded even better results. In the best variants, most hidden workers seemed willing to admit their "off-therecord" activities (8-20\% of all respondents of 16 years old or above admitted off-the-record activities), but the time spent on these activities and the amount earned remained heavily underestimated. An extra, compared to the aforementioned questionnaires, was that insight was gained into in which "industries" hidden work takes place. This information was used in all benchmark revisions of the national accounts since then.

This research was repeated between 2007 and 2010 (Kazemier, 2014). The number of respondents that admitted hidden work was less than in the abovementioned surveys. One of the reasons was that now less respondents on social benefits admitted hidden work. This is plausible, as now it is far more difficult to get a disablement benefit and the control by the social benefits organisations is far more sophisticated. Another reason was an increased perception of the chance to be caught, also by respondents not on social benefits. This is in line with the increased possibilities and the increased efforts of the tax authorities and the social security institutions to reduce fraud. Therefore, the conclusion can be drawn that the number of people working off the record has decreased since the early 1980s. Also new activities in which hidden work takes place, for example computer repair and website building, were observed. This latter result was taken into account in the benchmark revision of 2010 (Edens and Bruil, 2014; Statistics Netherlands, 2017).

In the meantime, the office had broadened its research to the value added of illegal activities. The first results of that research were presented in 1996 (van der Werf and van de Ven, 1996). Since then, this research was repeated and extended twice (Smekens and Verbruggen, 2005; Kazemier et al., 2013).

\section{Adjustments for exhaustiveness after the 2015 benchmark revision}

Statistics Netherlands follows an activity-specific approach. In the first step, activities and types of income are identified that are relevant in the context of exhaustiveness. In the second step, an estimate is made for each identified activity or type of income, using the most suitable method, given the available data sources.

The identified activities and types of income fit in Eurostat's tabular approach to identify types of inexhaustiveness (Figure 2). For the Netherlands, types N4, N5 and N7b are not relevant. Table 2 provides an overview of the various kinds of inexhaustiveness that were identified and provided with supplementary estimates in the 2015 benchmark revision. The explicit adjustments to assure exhaustiveness account for 2.3\% of GDP.

A characteristic of all adjustments for exhaustiveness is the lack of regular data. This forces statistical agencies to use incidental data sources for an estimate for the year the data refer to and then impute price and volume changes for the subsequent years until new data become available. Here, help from academia to develop more advanced methods for extrapolating incidental estimates of specific parts of the unobserved economy would be welcome. The next paragraphs describe how Statistics Netherlands has dealt with the lack of information to arrive at as good as possible estimate of the identified parts of the unobserved economy.

Table 2 presents all the explicit estimates to assure the exhaustiveness of the Dutch national accounts. This does not mean that national income would be lower by the same amount, if these explicit estimates were not made. Some elements of value added by illegal activities (type N2) are also included in other data sources used. For example, the consumption of cannabis in "coffee shops" is partly included in the data on the turnover of restaurants and cafes. For other activities, intermediate consumption would have been wrongly booked as final consumption and thus is included in the estimate of national income. This is, for example, the case for 
Tab. 2: Overview of estimates made for exhaustiveness, 2015

\begin{tabular}{|c|c|c|c|c|}
\hline & Type & Production & Intermediate consumption & Value added \\
\hline & & \multicolumn{3}{|c|}{ Million euros } \\
\hline $\begin{array}{l}\text { House renovations and main- } \\
\text { tenance }\end{array}$ & $\mathrm{N} 1$ & 1,485 & 743 & 742 \\
\hline Car repair and maintenance & $\mathrm{N} 1$ & 213 & 56 & 157 \\
\hline $\begin{array}{l}\text { Food/beverage service } \\
\text { activities }\end{array}$ & N1 & 280 & 49 & 231 \\
\hline Hairdressers and landscaping & $\mathrm{N} 1$ & 560 & 54 & 506 \\
\hline $\begin{array}{l}\text { Cleaning homes and other } \\
\text { buildings }\end{array}$ & N1 & 1,337 & 0 & 1,337 \\
\hline Babysitters and childcare & $\mathrm{N} 1$ & 316 & 0 & 316 \\
\hline Other & N1 & 373 & 11 & 362 \\
\hline Subtotal & N1 & 4,564 & 913 & 3,651 \\
\hline Cannabis & N2 & 4,053 & 1,137 & 2,916 \\
\hline Ecstasy, heroin, cocaine, etc. & N2 & 680 & 59 & 621 \\
\hline Smuggling cigarettes & N2 & 115 & 12 & 103 \\
\hline Fencing & N2 & 373 & 37 & 336 \\
\hline $\begin{array}{l}\text { Temporary employment } \\
\text { mediation }\end{array}$ & N2 & 316 & 16 & 300 \\
\hline $\begin{array}{l}\text { Illegal copying and illegal } \\
\text { gambling }\end{array}$ & N2 & 218 & 35 & 183 \\
\hline Prostitution & N2 & 607 & 214 & 393 \\
\hline $\begin{array}{l}\text { Adjustment for double } \\
\text { counting }\end{array}$ & & -512 & -421 & -91 \\
\hline Subtotal & N2 & 5,850 & 1,089 & 4,761 \\
\hline Own account construction & N3 & 208 & 151 & 57 \\
\hline Tips & N3 & 567 & 0 & 567 \\
\hline $\begin{array}{l}\text { Own account energy produc- } \\
\text { tion }\end{array}$ & N3 & 176 & 0 & 176 \\
\hline Renting of dwellings & N3 & 164 & 50 & 114 \\
\hline Other & N3 & 12 & 7 & 5 \\
\hline Subtotal & N3 & 1,127 & 208 & 919 \\
\hline Cost fraud & N6 & 0 & -763 & 763 \\
\hline Subtotal & N6 & 0 & -763 & 763 \\
\hline Income in kind & N7a & 158 & $-4,869$ & 5,027 \\
\hline $\begin{array}{l}\text { Functional approach of agricul- } \\
\text { ture }\end{array}$ & N8 & $-1,839$ & $-1,327$ & -512 \\
\hline VAT gap & N9 & 0 & -970 & 970 \\
\hline Subtotal & N7a-N9 & $-1,681$ & $-7,166$ & 5,485 \\
\hline Total & & 9,860 & $-5,719$ & 15,579 \\
\hline
\end{tabular}


electricity used to raise cannabis and clothes used by escorts for their work.

A detailed description of how the adjustments for exhaustiveness were estimated after the general benchmark revision 2010 can be found in Statistics Netherlands (2017). In the context of the benchmark revision 2015, all data sources, assumptions, ratios, etc., were carefully reconsidered and replaced by new ones if relevant information became available. An update of the inventory of sources and methods, or an annex to the recently published inventory of methods and sources used after the benchmark revision 2010 (Statistics Netherlands, 2017), will become available in some time. This update or annex will provide a detailed description of the estimates for exhaustiveness, including references to (research) papers consulted. Therefore, the outline below is kept brief. For illegal activities, only the major differences with what is already published (Kazemier et al., 2013; Statistics Netherlands, 2017) are mentioned.

In 2014, the Ministry of Finance (2014) published the results of an investigation on the VAT gap. In that research, they also examined the exhaustiveness adjustments (after the previous benchmark revision) made by Statistics Netherlands, by comparing them with the results of a thorough control of a sample of VAT returns. For many sectors, the adjustments made by Statistics Netherlands fit with the results of their sample. For some adjustment, for example for cafes and restaurants, they concluded that the adjustments might be a bit low. On the other hand, the exhaustiveness adjustments for construction were far higher than the results of their sample. Furthermore, they concluded that there are some branches in which they know that VAT evasion takes place, although Statistics Netherlands did not make adjustments. The results of this research are taken into account at the 2015 benchmark revision.

\subsection{Producers that should have registered but did not (N1)}

\subsubsection{House renovations and maintenance}

The estimate for off-the-record house renovation and maintenance consists of two parts. The first part is an estimate for the total amount spent on renovation and maintenance. The second is an estimate of the percentage paid off the record.

To arrive at an estimate for the total expenditure on renovation and maintenance, it is assumed that house owners spend, on average, $1 \%$ of the value of their house. According to mortgage lenders, homeowners should take this percentage into account. As tenants in the Netherlands are not responsible for the major maintenance of their home, it is assumed that they spend an average of 120 euros per year on, for example, incidental painting of the inside of their home. The intermediate use is assumed to account for half of the amount spent.

At the previous benchmark revision, it was assumed that $30 \%$ of the home maintenance was paid off the record. This assumption was based on a slightly outdated research report in 2004 and an estimate of a national association of homeowners (Vereniging Eigen Huis) in 2011. The same association recently published that currently a quarter of the homeowners are willing to pay off the record (Vereniging Eigen Huis, 2015). Therefore, the percentage used in the estimates is lowered to 20, assuming that not all homeowners who are prepared to pay off the record actually do.

As a result, the adjustment after revision for house renovations and maintenance is about $30 \%$ lower than the adjustment before revision. This is in line with the findings of the Ministry of Finance (2014). They concluded that the adjustments at the previous benchmark revision were about five times higher than the corrections they made for fraud. And, although there are various valid reasons for this, a lower adjustment is justified.

\subsubsection{Car repair and maintenance}

It is assumed that repair and maintenance of cars owned by a company (including lease cars) is not paid off the record. The same is assumed for privately owned cars for which a manufacturer warranty can still be made and for luxury brands cars like Bentley, Bugatti and Ferrari. This amounts to almost six million cars of which repair and maintenance might be paid off the record. The average amount yearly spent on maintenance is taken from the branch organisation (BOVAG - RAI Vereniging, 2017). The average price for repair is taken from a yearly 
publication of Rabobank (2017). It is assumed that 6-7\% of the maintenance is paid off the record and $10 \%$ of the repair, both for two-thirds of the official price.

\subsubsection{Food/beverage service activities}

It is assumed that $3 \%$ of the legal turnover in bars and cafes is kept hidden for the tax authorities. Off-the-record turnover in restaurants is assumed to be negligible as most payments are made electronically. This is a continuation of the method used before. The estimate for the intermediate use, however, is significantly adjusted downwards, resulting in a significantly higher (20\%) estimate for value added. Estimates for tips given in bars, cafes and restaurants are estimated separately and fall within exhaustiveness category N7a.

The adjustments are significantly higher than at the previous benchmark revision. This is in line with the findings of the Ministry of Finance (2014). In their report on the VAT gap, they conclude that the adjustments for the catering industry were very close to their lowest estimate and that an upward adjustment of the additional estimate is in place.

\subsubsection{Hairdressers}

In the literature and research reports on off-the-record income, no information was found on off-the-record income of hairdressers. Nevertheless, from survey research performed in the early 1980s of the previous century, it is known that this kind of off-the-record income exists (Section 3). Therefore, a discrepancy analysis was developed. Reported revenues from the business survey are compared with an estimated theoretical revenue. For the theoretical revenue, an expert guess was made of the number of hairdressing treatments (at home or in the barbershop) by gender and age. Moreover, it was assumed that $15 \%$ of all men and $10 \%$ of all women were offered hairdressing treatments by family members (which is considered to be a do-ityourself activity). Combined with the average price per treatment, gender and age, a theoretical turnover is calculated. The difference between the theoretical turnover and the turnover reported in the business surveys is assumed to be unobserved. However, unobserved (at home) hairdressing treatments are assumed to be $50 \%$ cheaper. Therefore, the estimate for unobserved hairdressing treatments is calculated as half of the difference between official and theoretical turnover. Intermediate consumption as share of the turnover for unobserved treatments is assumed to be equal to the share of observed treatments. For 2015, the value added of unobserved hairdressing treatments was estimated at slightly over 400 million euros.

\subsubsection{Landscaping}

From surveys on the hidden economy (van Eck and Kazemier, 1989; Kazemier, 2014), it is known that hidden work takes place in gardening and landscaping. However, data on the amount kept hidden from the tax authorities are not available, which necessitates an estimate. It was decided to add a mark-up of $5 \%$ to the output reported in the business survey of landscaping services (excluding by-products in this sector), based on the assumption that about half of the landscapers engage in hidden activities for 1 day per week during late spring to early autumn (6 months). Intermediate consumption was estimated based on business survey data. Furthermore, it was assumed that the employers' equipment was used. As a result, the value added of hidden landscaping was estimated at almost 100 million in 2015.

\subsubsection{Cleaning homes and other buildings}

From a recent research report on the market for services on households in 2013 (Commissie Dienstverlening aan huis, 2014), the potential market accommodates slightly $>950,000$ households in 2013 . This is $13 \%$ of all households in the Netherlands. Cleaning took about 120 million hours per year. Multiplied by the average hourly wage of 10.50 euros, the total turnover was almost 1,250 million euros in 2013. The time series is constructed by forward and backward extrapolation, using the change of the number of households for the extrapolation of the number of hours and the consumer price index for the hourly wage rate.

Likewise, an estimate is made for off-the-record cleaning of buildings and companies. As off-the-record 
cleaning is not very profitable and the detection rate and penalty are high, it is assumed that only $10 \%$ of the small companies (10 or less employees) in the Netherlands make use of hidden cleaning. Cleaning of a small office takes 5 hours per week ( 1 hour per working day), 48 weeks per year at a price similar to home cleaning. The total amount involved is almost 75 million euros in 2015.

\subsubsection{Babysitters and childcare}

At the 2010 general benchmark revision, the adjustment for babysitting and childcare included childcare by guest parents. Since then, a regular data source for childcare by guest parents subsidised by the government became available. Therefore, only childcare of children for which no government allowance is received is required. This is the case for about 300,000 children of 3 years or younger and 1.3 million children aged of 4-12 years. It is assumed that for $30 \%$ of the younger and $10 \%$ of the elder children, care is arranged for 10, respectively, 5 hours per week and 40 weeks per year at four euros per hour. In addition, there is some childcare by au pairs, students, etc.

\subsubsection{Other}

There is a range of activities that are not measured but whose impact on value added is relatively small: sweatshops, collection and sale of metal waste, unregistered taxis, ICT repair (e.g. by students), activities in the entertainment sector (e.g. music bands), tourism sector (e.g. tourist guides), etc.

\subsection{Illegal activities by producers that not need to be registered (N2)}

N2 contains the value added of illegal activities by producers that do not need to be registered. Part of the prostitution is not illegal in the Netherlands and should therefore be classified N3. However, the value added of all prostitution is labelled N2 for between-countrycomparability reasons. The same is true for illicit drugs. The sales of cannabis in the so-called "coffee shops" should be labelled N6 or N7 and the sales of ecstasy pills in dance clubs and at festivals and house parties, which is tolerated in the Netherlands, should be labelled N3. Also for the purpose of comparability between countries, the trade margin of both is labelled N2 here.

\subsubsection{Cannabis}

The estimates of the production and value added of cannabis are based on assumptions and data on the yield of a hemp plant per crop, the number of crops per year, data on prices, seizures and the chance to be caught. National consumption of cannabis is estimated by multiplying the number of users with the average use per user. Prices are easily available.

As the production of cannabis becomes more and more efficient, the average number of crops per year raises. Therefore, the number of crops used in the new calculations is raised from three to four. This number is also used by the police (Korps landelijke politiediensten, 2012). Moreover, the chance to be caught is lowered. According to the police, 5,000 out of approximately 25,000 stands are dismantled yearly, making the chance to be caught $20 \%$, whereas in earlier calculations $40 \%$ was assumed. The chance to be caught for imports of cannabis is lowered from 20 to $30 \%$. These fairly drastic adjustments lead to a considerably higher estimate of the value added of cannabis production and sales: more than twice as high as before.

\subsubsection{Ecstasy, heroin, cocaine, etc.}

The production and value added of the sales of ecstasy, heroin, cocaine, etc., are based on assumptions and data on the chance to be caught, seizures, prices and the number of addicts. New data have led to slightly different assumptions.

\subsubsection{Smuggling cigarettes}

Five per cent of all cigarettes sold in the Netherlands is assumed to be illegal. The volume of imported illegal tobacco and cigarettes is calculated from the volume seized and the chance of being caught. This volume is multiplied by the price of illegal cigarettes, being $30 \%$ of the price of legal cigarettes. 


\subsubsection{Fencing}

The value added of fencing is the total market value of stolen goods times the sales value as percentage of the market value times the trade margin of fencers times the share of stolen goods sold by fencers. New data on the market value of stolen goods and on the share of stolen goods sold by fencers became available (Ferwerda et al., 2016; Global Retail Theft Barometer, 2015; Kalidien, 2015; WODC, 2011). Using this new data resulted in a $30 \%$ higher estimate than before.

\subsubsection{Temporary employment mediation}

The production and value added of illegal temporary employment mediation is calculated as a fixed percentage $(3 \%)$ of the legal mediation. This percentage is based on a letter of the Minister to the parliament (Ministry of Social Affairs and Employment, 2014) and research by the Ministry of Social Affairs and Employment (2017).

\subsubsection{Illegal copying}

The turnover of illegal copies of music, movies and games is the number of illegal copies times the price of an illegal copy. The number of illegal copies is a percentage of the number of legally sold copies. The turnover of illegal copies of software is a percentage of the financial loss of the producers of software because of illegal copies. Since the rise of Netflix and the like, the sales of illegally copied movies and music have become considerably less lucrative. For that reason, the sales of illegal movies and games are assumed to be almost zero.

\subsubsection{Gambling}

The value added of illegal gambling is the total stake in illegal gambling houses, bingos, lotteries and e-games in the Netherlands minus pay-outs minus costs. Stakes in illegal gambling abroad, mainly e-games, are booked as imports.

\subsubsection{Prostitution}

Four types of prostitution are distinguished: window and street prostitution, prostitution in clubs, escort services and home prostitution. For each, the turnover of prostitution services is estimated from the supply side: the number of prostitutes times the number of clients per prostitute times the average price per client. Next, value added is turnover minus the costs minus the import of prostitution services. Costs include the costs of clothes, condoms, the travel expenses of escorts, the rent of rooms and windows and the payments to pimps. The incomes of prostitution services are the turnover of non-resident prostitutes.

The estimates of the value added of prostitution have been adjusted downwards. Data became available on the number of hours worked per week per prostitute (Husen and van Dijk, 2014). The working hours and consequently the number of clients per week are significantly less than was assumed: 28 hours per week instead of 40 hours. Furthermore, new data became available on the number of non-resident prostitutes, showing that there were slightly less non-resident prostitutes than assumed (Nijkamp et al., 2014; Daalder, 2015). Using these new data leads to a $33 \%$ lower estimate of the value added of prostitution than before.

\subsubsection{Adjustments for double counting}

Part of the illegal economy is already included in the business surveys, at least part of the value added of coffee shops, for example. In addition, final consumption of households include purchases which should be booked as intermediate consumption, as they are used in the production of cannabis (e.g. electricity) and in prostitution (e.g. clothes and condoms).

\subsection{Producers that are not obliged to register (N3)}

\subsubsection{Own account construction}

According to a research paper of 2004 of the Economic Institute for the Building Industry, over a quarter of all buildings built on behalf of a private person is built 
on own account (Lourens, 2004). As no more recent information is available, this percentage is also used for the estimates at the 2015 general benchmark revision. Combining this percentage with information from statistics on permits for construction and on houses built by ordering party, an estimate for own-account construction is made.

\subsubsection{Tips}

Giving a tip mainly occurs in taxis and in the hotel and catering industry (hotels, restaurants, bars and cafes). In earlier days, tipping also occurred at hairdressers, which is not the case anymore. The methods to estimate the amount of tips have not significantly changed.

\subsubsection{Own account energy production}

In 2015, households produced 780 million Kwh of solar energy, mainly for own consumption. This number is multiplied by the consumer price (thus including taxes on products; 0.23 euros per Kwh in 2015).

\subsubsection{Renting of dwellings}

Private renting of rooms to tourists has increased significantly over the last few years. Data on these Airbnb-type activities can be found on the internet. Mediation services on the internet cover some $80 \%$ of the market. The total received rental via these fora amounted to 188 million euros in 2016. One year previously, this total stood at 158 million euros. A mark-up for cleaning at 30 euros per visit results in an amount of 14 million euros. Grossing up for the full market results in an estimate of 215 million euros in 2015.

Counting has been doubled as the regular estimate for the imputed income from owner-occupied dwellings is not corrected for these commercial activities. This double counting amounts to about 41 million euros. The intermediate costs of renting these rooms - energy, cleaning products, intermediation costs, etc. - is estimated at 50 million euros.

\subsubsection{Other}

In addition to the four above-mentioned N3 adjustments, there are some minor adjustments for kitchen gardens, the delivery of newspapers and (advertisement) leaflets, private music lessons and private tutoring.

\subsection{Misreporting by producers (N6)}

\subsubsection{Cost fraud}

There are two ways to evade taxation. The first is to under-declare turnover, the second is to over-declare intermediate costs. Turnover fraud is corrected for by increasing the production estimates (both value added and intermediate consumption). Adjustments for this type of fraud are mentioned in the previous sections. Cost fraud is corrected for by reducing intermediate consumption and increasing value added by the same amount.

Cost fraud is assumed to occur mainly in small enterprises. The involvement of a high number of people in larger enterprises generally makes fraud too difficult to keep it hidden. It is assumed that the larger firms will therefore use other (legal) ways to reduce taxation.

The expenditure of enterprises with fewer than 10 employees was determined for all industries in which substantial cost fraud is suspected. It was assumed that cost fraud amounts to $10 \%$ of total turnover for these smaller enterprises. Cost fraud mainly occurs in the textiles and leather industry, construction, trade and repair, hotels, restaurants and cafes, health care and the commercial services.

\subsection{Other adjustments (N7-N9)}

\subsubsection{Income in kind}

Although most of the income in kind is observed, it is booked incorrectly as intermediate consumption. However, as it is not explicitly observed as compensation of employees, the adjustments for all income in kind are labelled N7a.

Wages and salaries in company accounts do not match with the definition of compensation of employees 
in the national accounts. For example, wages according to company accounts do not include the costs of companycar use, interest discounts and meals. In company accounts, the amounts involved are considered as costs, whereas the national accounts identify these as income in kind. This means that part of the intermediate costs must be converted to compensation of employees and thus to value added.

The most relevant items, in terms of money involved, are the use of company cars, free transport services for employees working in public transport (buses and railways) and aviation companies, meals and drinks offered by the employer in the office and during business trips. Interest reductions on mortgages for staff of banks and Christmas presents and the like of employers to their employees. Sources are available to base an estimate on for all these data. This has not changed at the 2015 benchmark revision.

Corrections for other differences between company accounts and national accounts, like payments during sick leave, do not affect national accounts and therefore fall outside the scope of adjustments for exhaustiveness.

\subsubsection{Functional approach of agriculture}

Because of the functional, product-based approach of agriculture in the national accounts, production, intermediate use and value added from side activities have to be removed.

\subsubsection{VAT gap}

In the first instance, only VAT is included that is gathered by the treasury. However, not all VAT that is raised is actually handed over. This is, for example, the case when a company goes bankrupt and does not have enough money left to compensate treasury for missed VAT. Furthermore, companies in the Netherlands that have to hand over $<1,883$ euros on VAT in a certain year, get a deduction on their VAT bill. Moreover, companies whose annual VAT bill is $<1,345$ euros may keep the VAT they raised and do not have to hand over any VAT whatsoever. Finally, there is intra-community VAT fraud. This, together with the effect of some booking conventions in the Dutch national accounts leads to an estimate of 970 million euros VAT (of which 434 million euros from intra-community fraud) that is actually paid but not included in the figures of the treasury.

The amount of VAT that should be raised but is not, for instance in illegal and off-the-record transactions, equals to 648 million euros in 2015. However, this should not be included in the national accounts.

\subsection{Annual updates}

Estimates of exhaustiveness are updated annually. When annual data sources are available, these sources are used for the annual update. When annual data are lacking, indicators such as the number of male inhabitants in the Netherlands aged 18 years or above (for prostitution), prices and growth rates in specific NACE activities (e.g. for unrecorded home repair and unrecorded hairdressing) are used. Other parameters used in the activity-specific methods, such as seizure rates for drugs and the percentage of cars maintained off the record, are usually kept constant over time, due to the absence of reliable and comparable annual data. Methodological revisions as well as the introduction of new unobserved activities only occur at benchmark revisions.

\section{Estimates for illegal activities in Europe}

Comparing the adjustments for all types of exhaustiveness over time is difficult, as adjustments for exhaustiveness are adjustments for missing observation. However, as soon as the observation of activities improves, for example by introducing new or more advanced business and household surveys (increased availability of registers), the size of the unobserved activities decreases and the adjustments for exhaustiveness most likely decreases as well. The same is even more true for a comparison between countries. Laws differ between countries, countries have different statistical systems, statistical agencies have different opportunities for observation and so on, making the size of the adjustments for exhaustiveness differ between countries. In addition, a comparison between countries of the total adjustments for exhaustiveness is practically impossible. Many statistical agencies do not publish 
Tab. 3: Time series of the contribution of illegal activities (N2) to GDP

\begin{tabular}{|c|c|c|c|c|c|c|c|c|}
\hline & Bulgaria & Cyprus & Czech Republic & Ireland & Latvia & Poland & Romania & United Kingdom \\
\hline & $\%$ of GDP & & & & & & & \\
\hline 1995 & . & . & . & . & 0.99 & 0.64 & . & . \\
\hline 1996 & . & . & . & . & 1.11 & . & . & . \\
\hline 1997 & . & . & . & . & 0.92 & . & . & 0.92 \\
\hline 1998 & . & . & . & . & 1.59 & . & . & 0.87 \\
\hline 1999 & . & . & . & . & 1.22 & . & . & 0.82 \\
\hline 2000 & . & . & . & . & 0.93 & . & . & 0.77 \\
\hline 2001 & . & . & . & . & 0.88 & . & . & 0.72 \\
\hline 2002 & . & . & . & . & 0.89 & . & . & 0.68 \\
\hline 2003 & . & . & . & . & 0.97 & . & . & 0.61 \\
\hline 2004 & . & . & . & . & 0.91 & . & . & 0.63 \\
\hline 2005 & . & . & 0.59 & . & 0.87 & 0.48 & . & 0.62 \\
\hline 2006 & . & . & 0.49 & . & 0.78 & . & . & 0.71 \\
\hline 2007 & . & . & 0.42 & . & 0.70 & . & 0.46 & 0.68 \\
\hline 2008 & 0.28 & . & 0.37 & . & 0.73 & . & 0.38 & 0.62 \\
\hline 2009 & 0.28 & . & 0.38 & . & 0.99 & . & 0.38 & 0.63 \\
\hline 2010 & 0.21 & 0.8 & . & 0.73 & 1.30 & 0.65 & 0.47 & 0.56 \\
\hline 2011 & 0.22 & 0.5 & . & 0.72 & 1.11 & 0.68 & 0.31 & 0.55 \\
\hline 2012 & 0.23 & 0.4 & . & 0.70 & 1.00 & 0.78 & 0.30 & 0.50 \\
\hline 2013 & 0.27 & 0.4 & . & 0.72 & . & 0.79 & 0.28 & . \\
\hline 2014 & 0.25 & . & . & . & . & . & . & . \\
\hline
\end{tabular}

the total exhaustiveness adjustments. This is even true for several countries that do publish their inventory of methods and sources as well as their estimates of illegal activities.

The only kind of adjustment for exhaustiveness for which enough data are available and for which a comparison between countries may make sense are the estimates for illegal activities. And even this comparison may not be complete. By definition, illegal activities by producers in an administrative register, enterprise survey or administrative collection, fall outside the scope of N2. The prostitution in France and Germany is a representative example. To a large extent, prostitution is legal in these countries, making France and Germany exclude the estimates for this activity in N2. An additional reason that between-country comparison is not entirely fair, is the difference per country in the number of illegal activities adjusted for. Many countries only adjust for prostitution, illicit drugs and smuggle, whereas other countries, such as the Netherlands, adjust for a wider range of illegal activities.

Figure 3 presents the contribution of N2 illegal activities to GDP after the ESA 2010 benchmark revision in all but one EU member states and Norway. The first inventory of estimates for the value added of illegal activities was published by Kazemier and Rensman (2015). For some countries, they used the inventories written after the ESA95 revision. Furthermore, they used sources found on the internet, such as press releases, documents on the websites of the statistical agencies, articles and interviews in newspapers, etc. In the meantime, inventories on the sources and methods used in compiling national accounts according to ESA 2010 became public on the internet for Austria, Belgium, 
Denmark, Estonia, Finland, France, Germany, Malta, the Netherlands and Sweden. For other countries, papers and articles with more detailed information were published. These inventories, papers and articles allowed for an update of the figures published earlier. ${ }^{1}$ More information can be found in the Appendix. In almost all countries in Figure 3, illegal activities (including legal prostitution and legal sales and use of drugs) contribute $<1 \%$ to GDP.

InFigure 3, a distinction is made between adjustments because of prostitution, the production and trade of illicit drugs, smuggle of tobacco and alcoholics and other illegal activities. The first three were mandatory, the latter were not. Most countries only include estimates for the three types that were obliged. Malta and Sweden also include estimates for illicit gambling, the Czech Republic adds estimates for copyright infringements, ${ }^{2}$ Croatia adds estimates for illegal production of tobacco, wine and liquors and the Netherlands adds estimates for illegal gambling, fencing, copyright infringements and illegal temporary employment mediation.

Luxembourg, Malta and the United Kingdom do not estimate the value added of smuggling. On the other hand, other countries publish figures for smuggle of tobacco and alcoholics combined with the smuggle of motor fuels and medicines (Estonia), the production of alcoholic beverages (Czech Republic), or the smuggle of wine, soft drinks, chocolate and sweets (Denmark). Spain only provides a figure for smuggle combined with illegal gambling. For these countries, it is assumed that half of the figure for smuggle relates to the smuggle of tobacco and alcoholic beverages. The remainder is labelled as "other illegal activities".

In some countries, for example the Netherlands, Germany and France, part of prostitution is not illegal. France and Germany even say that legal prostitution has been included in GDP for a long time. For the sake of comparability, their estimates for legal prostitution are here considered to be part of the illegal economy and included in Figure 3. The German inventory of methods and sources used provides information for 2010 on the

1 If estimates in euros or local currency are available, percentages are calculated using GDP retrieved from the online database of Eurostat on 16 July 2018, otherwise the percentages published are used.

2 They also claim to include estimates for the smuggle of fuels and fencing stolen cars. However, no explicit estimates for these types of illegal activities were found. turnover and intermediate use of prostitution (Destatis, 2016).

France does not include estimates for illicit drugs and illegal prostitution in their national accounts. They think that drug addicts and illegal prostitutes do not act voluntarily. Therefore, transactions with addicts and illegal prostitutes are without mutual consent and fall outside the production boundary of the national accounts. However, for EU budgetary purposes France provides Eurostat with an estimate of GNI that includes the value added of these activities. Figures for legal and illegal prostitution and illicit drugs are found in France's inventory of methods and sources (Insee, n.d.).

At the previous general benchmark revision, the estimate of the contribution of illegal activities in the Netherlands was just below EU average. Due to the substantial upward adjustment of the value added of cannabis, the contribution of illegal activities in the Netherlands to GDP is now about $0.2 \%$ of GDP above EU28 average. Over half of this difference is due to the inclusion of other illegal activities.

Several countries published time series of the contribution of illegal activities, see Table 3. In many countries for which data are available, the share of illegal activities in GDP decreases. Only the figures for Poland show a significant increase.

\section{Conclusions}

An important characteristic of the adjustments for exhaustiveness is the lack of regularly available source data. Most of the time, the source data do not cover the full subject. Expert judgement plays an important role. This is especially the case for activities that are kept hidden for the tax authorities and for illegal activities. Precisely, this has always been an important reason for Statistics Netherlands to be open about the sources and methods used and the assumptions applied. It is an implicit invitation to researchers and specialist at

3 For Croatia and Lithuania, only the average annual contributions in 2002-2012 and 2000-2010, respectively, are known. For Hungary, the value added of illicit drugs and prostitution were included at the implementation of ESA 95, base year 2002. Smuggling of tobacco was included at the implementation of ESA 2010. It is assumed that the relative contribution of illicit drugs and prostitution in 2010 is the same as in 2002. 


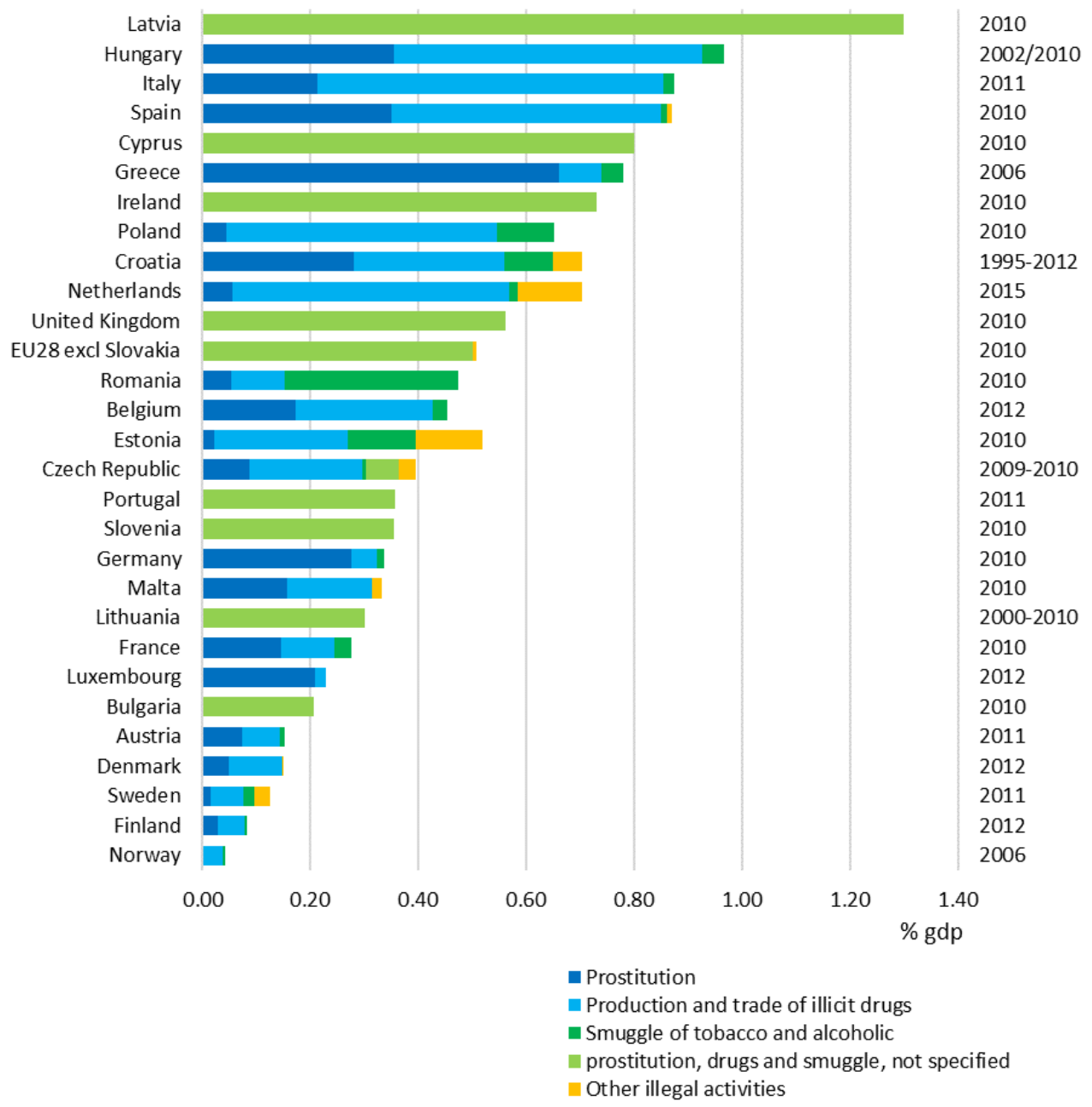

Fig. 3: The value added of N2 illegal activities. ${ }^{3}$

universities and government agencies to come up with well documented and proven better estimates.

Statistics Netherlands consider their estimates for exhaustiveness as the best estimates possible, given the data sources and literature available. Nevertheless, they continually work to improve the quality and reliability of these adjustments. Also at the recent 2015 benchmark revision, performed in 2017 and 2018, the quality and coverage of the exhaustiveness adjustments are improved: additional data sources and recent published results of research in the field are used and estimates of some recent phenomena like Airbnb and own account solar energy production are introduced. On the other hand, some existing exhaustiveness adjustments are replaced by estimates based on regular data sources and therefore no longer fall within the adjustments for exhaustiveness. This is, for instance, the case with some adjustments for double counting, mentioned in Statistics Netherlands (2017) and for part of the adjustments for babysitters and childcare.

The exhaustiveness adjustments for 2015 after the recent general benchmark revision count for $2.3 \%$ of GDP. The largest adjustments are for income in kind and for illegal activities. In 2015, GDP includes 4,852 million euros because of illegal activities, which is $0.70 \%$ of GDP. Adjustments for tax evasion are not explicitly labelled as such. However, with some simple assumptions, the total adjustment for tax evasion may be estimated at 3,900 million euros (Table 4 ) or $0.57 \%$ of GDP.

Although the exhaustiveness adjustments are relatively small, the inclusion of these estimates significantly decreases the systematic downward bias 
Tab. 4: A tentative estimate of the adjustment for tax evasion, 2015

\begin{tabular}{lllll}
\hline & Type & Value added & Share tax evasion & $\begin{array}{l}\text { Value added hidden because } \\
\text { of tax evasion }\end{array}$ \\
\hline House renovations and maintenance & N1 & Million euros & $\%$ & Million euros \\
\hline Car repair and maintenance & N1 & 742 & 100 & 742 \\
\hline Food/beverage service activities & N1 & 157 & 100 & 157 \\
\hline Hairdressers and landscaping & N1 & 231 & 100 & 231 \\
\hline Cleaning homes and other buildings & N1 & 506 & 50 & 253 \\
\hline Babysitters and childcare & N1 & 1,337 & 50 & 158 \\
\hline Other & N1 & 316 & 50 & 181 \\
\hline Tips & N3 & 362 & 50 & 283 \\
\hline Renting of dwellings & N3 & 567 & 50 & 29 \\
\hline Cost fraud & N6 & 114 & 25 & 763 \\
\hline VAT gap (intra-community fraud) & N9 & 763 & 100 & 100 \\
\hline Total & 434 & & 434
\end{tabular}

of the official estimates of GDP. Furthermore, it slightly affects the GNI-based contribution of the member countries to the budget of the EU. The inclusion of the value added of illegal activities, for example (Figure 3), has led to an increase of the GNI-based contribution of all member states that reported an above EU-average adjustment because of illegal activities.

\section{References}

[1] Bikker, R., Daalmans, J., \& Mushkudiani, N. (2013). Benchmarking large accounting frameworks: A generalized multivariate model. Economic Systems Research, 25(4), 390-408.

[2] Bonger, W. A. (1915). Vermogen en inkomen in Nederland (II, 1908-1913). De Nieuwe Tijd 20: 226-249 and 269-291. [Capital and income in the Netherlands]

[3] Bonger, W. A. (1923). Vermogen en inkomen in Nederland gedurende de oorlogstijd (1913-1920). Amsterdam: Ontwikkeling. [Capital and income in the Netherlands during the war]

[4] BOVAG - RAI Vereniging. (2017). BOVAG-RAI Aftersales Monitor 2016.
[5] Broesterhuizen, G. A. A. M. (1985). The unobserved sector and the national accounts in the Netherlands. In W. Gaertner \& A. Wenig (Eds.), The Economics of the Shadow Economy: Conference Proceedings Bielefeld (pp. 105-126). Berlin, German: Springer Verlag.

[6] Calzaroni, M. (2000). The exhaustiveness of production estimates: New concepts and methodologies. Proceedings of the International Conference on Establishment Surveys, Buffalo, 2000, Statistics Canada, Ottawa.

[7] Central Statistical Bureau Latvia. (2014). Changes in the calculation of gross domestic product were carried out. Press release 30 September 2014.

[8] Central Statistical Office. (2014). Implementing New International Standards for National Accounts and Balance of Payments Statistics. Press release 3 July 2014.

[9] Commissie Dienstverlening aan huis. (2014). Dienstverlening aan huis: wie betaalt de rekening? Advies commissie Dienstverlening aan huis. Zoetermeer: Panteia. [Home services: who pays the bill? Advice of the commission on home services]

[10] Croatian Bureau of Statistics. (2014). Notes on methodology; Gross domestic product and main 
aggregates of national accounts. Press release 10 September 2014.

[11] Cystat. (2014). Revision of national accounts 19952013.

[12] Czech Statistical Office. (n.d)(a). Annexes: Main revision 2011.

[13] Czech Statistical Office. (n.d)(b). Quality report 2014; Czech republic.

[14] Czech Statistical Office. (2010). Gross national income inventory 200, Czech Republic, 2002.

[15] Daalder, A. L. (2015). Prostitutie in Nederland anno 2014. Cahier 2015-1 (WODC). [Prostitution in the Netherlands anno 2014].

[16] Danmarks Statistik. (2016). Danish GDP and GNI, Sources and methods, 2012.

[17] de Langen, J. W. (1939). Enkele ontwikkelingen over de controle en repressiemiddelen van de fiscus. Geschriften van de Vereeniging voor Belastingwetenschap 48. Purmerend: Muusses. [Some developments of the control and repression of the tax authorities]

[18] Derksen, J. B. D. (1939). Berekening van het Nationale vermogen uit de aangiften van de successiebelasting. De Nederlandse Conjunctuur $(\mathrm{X})$ : 72-77. [Calculation of the national capital from the returns of the inheritance tax].

[19] Destatis. (2016). National Accounts; Domestic product and national income in accordance with ESA 2010; Methods and Sources; Edition 2016.

[20] Edens, B., \& Bruil, A. (2014). Inclusion of non-observed economy in Dutch national accounts after the 2010 ESA revision. The Hague, Netherlands: Statistics Netherlands.

[21] European Parliament. (2016). Answer given by $\mathrm{Mr}$ Almunia on behalf of the Commission. Parliamentary questions 7 November 2006.

[22] Eurostat. (2013). European system of accounts, ESA 2010. Official Journal of the European Union L174, 56.

[23] Evensen, T. N. (2011). Illegal økonomi i nasjonalregnskapet. Notater 16/2011. Oslo, Norway: Statistics Norway. [Illegal economy in the national accounts].

[24] Feige, E. L. (1979). How big is the irregular economy? Challenge, 22(5), 5-13.

[25] Ferwerda, H., van Ham, T., Scholten, L., \& Jager, D. (2016). Focus op heling: een onderzoek naar het functioneren van de helingmarkt, het beleid tegen en de gevolgen van heling. Arnhem, Netherlands: Bureau Beke. [Focus on fencing: an investigation into the functioning of the fencing market, the policy against and the effects of fencing].

[26] Gimming, K., Halvorsen, T., Skoglund, T., \& Sørensen, K. Ø (2011). Revised national accounts figures 1970-2010. Economic Survey, 2011(4), 20-27.

[27] Global Retail Theft Barometer. (2015). The new barometer 2014-2015. Thorofare, NJ: Checkpoint Systems.

[28] Helfferich, K. (1914). Deutschlands Volkswohlstand 1888-1913. Berlin, German: Verlag van Georg Silke. [Germany's national wealth 1888-1913].f

[29] Hungarian Central Statistical Office. (2011). GNI Inventory of Hungary, version 2.2.

[30] Hungarian Central Statistical Office. (2014). National accounts of Hungary, 2013 (preliminary data).

[31] Husen, G., \& van Dijk, T. (2014). In gesprek met de klant: een onderzoek naar klanten van prostituees en hun rol bij de aanpak van misstanden. E\&G reeks 2014/3. Amsterdam, Ther Netherlands: GGD. [In conversation with the client: an investigation into clients of prostitution and their role in tackling abuses].

[32] Insee. (n.d.). ESA 2010 GNI inventory - France.

[33] Instituto Nacional de Estadística. (2014). Spanish National Accounts,. New base 2010; 2010-2013 Series. Press release, 25 September 2014 (updated on 3 October).

[34] ISTAT. (2014). Summary of the Esa2010 Revision of National Accounts, Year 2011. Press release 9 September 2014.

[35] ISTAT. (2015). Non observed economy in national accounts, years 2011-2013. Press release 4 December 2015.

[36] Kahoun, J. (2012). Revision of regional accounts 2011. Statistica, 49(2), 62-75.

[37] Kalidien, S. N. (ed). (2015). Criminaliteit en rechtshandhaving 2015: ontwikkelingen en samenhangen (Raad voor de rechtspraak, Statistics Netherlands, Boomcriminologie, WODC). [Crime and law enforcement 2015: development and coherence].

[38] Kazemier, B. (1984). De enquête woningonderhoud en -verbetering: een onderzoek naar het zwarte circuit. Statistisch Magazine, 4(1), 31-38. Voorburg/ 
Heerlen: Statistics Netherlands [The survey on home repair and home improvement: a research into the hidden economy].

[39] Kazemier, B. (2006). Monitoring the Underground Economy - A Survey of methods and Estimates. In H. Enste \& F. Schneider (Eds.), Jahrbuch Schattenwirtschaft 2006/2007; Zum Spannungsfeld von Politik und Ökonomie (pp. 11-53). Vienna/Berlin, Austria/German: Lit Verlag.

[40] Kazemier, B. (2014). Hidden workers and hidden worker potential in the Netherlands. Economic Analysis and Policy, 44, 39-50.

[41] Kazemier, B., Bruil, A., van deSteeg, A., \& Rensman, M. (2013). The contribution of illegal activities to national income in the Netherlands. Public Finance Review, 41(5), 544-577.

[42] Kazemier, B., \& Rensman, M. (2015). De illegale economie en national inkomen. Justitiële verkenningen, 41(1), 35-50. [The illegal economy and national income].

[43] Korps landelijke politiediensten. (2012). Nationaal dreigingsbeeld 2012. Georganiseerde criminaliteit. Zoetermeer: KLPD. [National threat assessment 2012. Organized crime].

[44] Kuksin. (2013). Prostitution. Ein normales Gewerbe seit der Legalisierung über das Prostitutionsgesetz? (Hausarbeit 2013). Hamburg: University of Hamburg. [Prositution. A normal business since the legalization of the Prostitution Act?].

[45] Kuznets, S. (1941). National income and its composition, 1919-1938. New York, NY: National Bureau of Economic Research.

[46] Lourens, E. (2004). Bouwen in eigen beheer en onrechtmatige bedrijfsuitoefening in 2003. Amsterdam, Netherlands: EIB. [Own-account construction and clandestine business].

[47] Markelevičius, J. (2011). Revision of time series of gross domestic product and gross national income in Lithuania for 2000-2010. Vilnius, Lithuania: Statistics Lithuania.

[48] Ministry of Finance. (2014). Onderzoek naar macroeconomische schatting van gemiste omzetbelasting (btw gap). [Research into a macro-economic estimate of missed sales-tax (vat gap)].

[49] Ministry of Social Affairs and Employment. (2014). Aanpak malafide uitzendbureaus en zelfregulering.
[Tackling malicious employment agencies and selfregulation]

[50] Ministry of Social Affairs and Employment. (2017). Eerlijk werk door uitzendbureaus 2016. [Honest work by employment agencies]

[51] National Bank of Belgium. (2017). Gross National Income, Methodological inventory Belgium, ESA 2010.

[52] National Institute of Statistics Romenia. (n.d.). Estemarea Activităților ilegale în România. [Estimates of illegal activities in Romania]

[53] National Statistics Office Malta. (2015). Gross National Income Inventory European System of Accounts 2010; Sources and Methods for the Compilation of the Gross National Income for the Maltese Islands.

[54] Nijkamp, R., Sijtstra, M., Snippe, J., \& Bieleman, B. (2014). VERBODEN ROOD IN BEELD: Onderzoek aard en omvang niet-legale prostitutie in 2014. Rotterdam, Netherlands: Intraval, GronenRotterdam. [A picture of prohibited red: a research into the nature and size of non-legal prostitution].

[55] OECD/IMF/ILO/CIS STAT. (2002). Measuring the non-observed economy; A handbook. Paris: OECD.

[56] Office for National Statistics. (2014a). National Accounts Articles - Impact of ESA95 Changes on Current Price GDP Estimates.

[57] Office for National Statistics. (2014b). Impact of Blue Book 2014 changes on GDP at current market prices, Annex F (excel-sheet).

[58] Rabobank. (2017). Branche-informatie: Schadeherstelbedrijven, Rabobank Cijfers $\mathcal{E}$ Trends 2 July 2017. [Branche-information: (Car) repair companies]

[59] Reuters. (2016). Press Digest - Bulgaria - Oct 1.

[60] Schneider, F., \& Buehn, A. (2018). Shadow economy: Estimation methods, problems, results and open questions. Open Economics, 2018(1), 1-29.

[61] Smekens, M., \& Verbruggen, M. (2005). The illegal economy in the Netherlands. Discussion paper 05005. Voorburg, South Holland: Statistics Netherlands.

[62] Statistični urad Republike Slovenije. (2013). GDP exhaustiveness adjustments and shadow economy, Slovenia, 2010. Press release June 27, 2013, Special release.

[63] Statistics Austria. (2016). Inventory of methods for national accounts in Austria according to ESA2010, version March 2016. 
[64] Statistics Estonia. (2017). Gross National Income Inventory ESA 2010; 3. Version; Estonia.

[65] Statistics Finland. (2016). ESA 2010 GNI Inventory, Finland, version May 2016.

[66] Statistics Netherlands. (2017). Gross National Income Inventory (ESA 2010), 2010 The Netherlands.

[67] Statistics Poland. (2015). Notatka informacyjna. Press release 29 September 2014.

[68] Statistics Portugal. (2017). Revision policy of the Portuguese National Accounts System; Benchmark-year 2011.

[69] Statistics Sweden. (2016). Sweden GNI Inventory. March 2016 (Rev. Oct 2016).

[70] Statistics Netherlands. (1951). Statistische en Econometrische verkenningen. 6(4), 168-180.

[71] van der Werf, R., \& van de Ven, P. (1996). The illegal economy in the Netherlands. Paper presented at the 24th General Conference of the International Association for Research in Income and Wealth, Lillehammer, Norway, 18-24 August, 1996.

[72] van Eck, R., \& Kazemier, B. (1988). Features of the hidden economy in the Netherlands. Review of Income and Wealth, 34(3), 251-273.

[73] van Eck, R., \& Kazemier, B. (1989). Zwarte arbeid, een empirische en methodologische studie. (PhD. Thesis, University of Amsterdam). [Hidden labour, an empirical and methodological study]

[74] Vereniging Eigen Huis. (2015). Zwartwerken: getolereerd maar niet zonder risico's (press release, August 16, 2015). [Hidden work: tolerated but not without risk]

[75] Weber, O., \& Emprou, J.-M. (2014). Sur l'impact de l'économie illégale sur l'économie Luxembourgeoise. Regards 13 (July 2014). [On the impact of the illegal economy on the Luxembourg economy]

[76] WODC. (2011). Monitor Criminaliteit Bedrijfsleven 2010: Feiten en trends inzake aard en omvang van criminaliteit in het bedriffsleven. The Hague, Netherlands: WODC. [Monitor Crime in Business 2010: Facts and trends in the nature and scale of crime in business]. 


\section{Appendix}

In 2014, countries in the EU revised their national accounts and introduced ESA 2010 (Eurostat, 2013). At the same occasion, an estimate of the value added generated by illegal activities was included in GDP. Countries were obliged to include the value added of the production, smuggle and sales of illicit drugs, the value added of prostitution and the value added of the production, smuggle and sales of tobacco. Countries were free to include other kinds of illegal activities and several countries did. Some countries had already included the value added of illegal activities before. They continued and sometimes revised their estimates of illegal activities (Table A1).

Table A1. The contribution of illegal activities to GDP in Europe

\begin{tabular}{|c|c|c|c|}
\hline & & Value added of illegal activities as $\%$ of GDP & Sources \\
\hline Austria & 2011 & 0.15 & Statistics Austria (2016), p. 307, p. $312^{\text {a }}$ \\
\hline Belgium & 2012 & 0.45 & National Bank of Belgium (2017), p. 604 \\
\hline Bulgaria & 2010 & 0.21 & Reuters (2016); Presentation by M. Kolev, Sofia, 2016 \\
\hline Croatia & $1995-2012^{d}$ & 0.70 & Croatian Bureau of Statistics $(2014)^{c}$ \\
\hline Cyprus & 2010 & 0.80 & Cystat $(2014)^{b}$ \\
\hline Czech Republic & $2009-2010$ & 0.40 & Czech Statistical Office (2010) ${ }^{\mathrm{b}}$, (a), (b); Kahoun (2012) \\
\hline Denmark & 2012 & 0.15 & Danmarks Statistik (2016), p. 209a \\
\hline Estonia & 2010 & 0.52 & Statistics Estonia (2017) ${ }^{\mathrm{a}}$ \\
\hline Finland & 2012 & 0.08 & Statistics Finland (2016), p. 359 a \\
\hline France & 2010 & 0.28 & Insee (n.d.), p. 13, p. $277^{\text {a }}$ \\
\hline Germany & 2010 & 0.34 & Destatis (2016), p. 359, p. 490, p. $501^{\text {a }}$ \\
\hline Greece & 2006 & 0.78 & European Parliament (2016) \\
\hline Hungary & $2002-2010^{e}$ & 0.97 & Hungarian Central Statistical Office $\left(2011^{\mathrm{b}}, \mathrm{2}^{2014)}\right.$ \\
\hline Ireland & 2010 & 0.73 & Central Statistical Office $(2014)^{c}$ \\
\hline Italy & 2011 & 0.87 & ISTAT $(2014,2015)^{c}$ \\
\hline Latvia & 2010 & 1.30 & Annex at Central Statistical Bureau Latvia (2014) ${ }^{c}$ \\
\hline Lithuania & $2000-2010^{d}$ & 0.30 & Markelevičius (2011) c \\
\hline Luxembourg & 2012 & 0.23 & Weber and Emprou (2014) \\
\hline Malta & 2010 & 0.33 & National Statistics Office Malta (2015), pp. 467-470a \\
\hline Netherlands & 2015 & 0.70 & \\
\hline Poland & 2010 & 0.65 & Statistics Poland $(2015)^{c}$ \\
\hline Portugal & 2011 & 0.36 & Statistics Portugal (2017) \\
\hline Romania & 2010 & 0.47 & National Institute of Statistics Romenia (n.d.) \\
\hline \multicolumn{4}{|l|}{ Slovakia } \\
\hline Slovenia & 2010 & 0.36 & Statistični urad Republike Slovenije (2013) c \\
\hline Spain & 2010 & 0.87 & Instituto Nacional de Estadística (2014) ${ }^{c}$ \\
\hline Sweden & 2011 & 0.13 & Statistics Sweden (2016), p. 392 \\
\hline United Kingdom & 2010 & 0.56 & Office for National Statistics (2014a, 2014b) \\
\hline
\end{tabular}


Continued Table A1. The contribution of illegal activities to GDP in Europe

Value added of illegal activities as \% of GDP Sources

\begin{tabular}{llll} 
& & Value added of illegal activities as \% of GDP & Sources \\
\hline EU28 & 2010 & 0.51 & \\
Norway & 2008 & 0.04 & $\begin{array}{l}\text { Gimming, Halvorsen, Skoglund, and Sørensen (2011), } \\
\text { Evensen (2011) }\end{array}$ \\
\hline
\end{tabular}

anventory ESA 2010.

'Inventory ESA 95.

cPress release.

${ }^{\mathrm{d}}$ Average for the specified period.

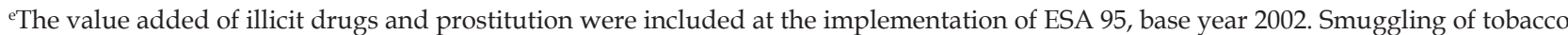
was included at the implementation of ESA 2010. It is assumed that the relative contribution of illicit drugs and prostitution in 2010 is the same as in 2002.

fThe weighted average of the member states of the EU, excl. Slovakia; weighted by GDP 2010. 